\title{
Influence of electrical stimulation on peripheral nerve regeneration: Protocol for a
}

\section{systematic review}

\author{
Influência da estimullação elétrica na regeneração nervosa periférica: Protocolo para uma revisão \\ sistemática
}

Influencia de la estimulación eléctrica en la regeneración de los nervios periféricos: Protocolo para una revisión sistemática

Received: 12/19/2021 | Reviewed: 12/24/2021 | Accept: 12/25/2021| Published: 12/27/2021

\author{
Enilton de Santana Ribeiro de Mattos \\ ORCID: https://orcid.org/0000-0003-2039-9744 \\ Federal University of Bahia, Brazil \\ E-mail: eniltonmattos@hotmail.com \\ Alex Guedes \\ ORCID: https://orcid.org/0000-0001-7013-7107 \\ Federal University of Bahia, Brazil \\ Santa Izabel Hosptal, Holy House of Mercy of Bahia, Brazil \\ E-mail: alexguedes2003@yahoo.com.br \\ Mateus dos Santos Viana \\ ORCID: https://orcid.org/0000-0001-9021-7657 \\ Federal University of Bahia, Brazil \\ E-mail: vianamateus@hotmail.com \\ Abrahão Fontes Baptista \\ ORCID: https://orcid.org/0000-0001-7870-3820 \\ Federal University of ABC, Brazil \\ São Paulo University, Brazil \\ E-mail: abrahao.baptista@gmail.com
}

\begin{abstract}
This is a protocol for a systematic review (intervention). Electrical stimulation (ES) is a therapeutic strategy used to improve peripheral nerve regeneration that involves the application of electrical fields of constant or varying frequency. We are going to lead a literature search to identify all published and unpublished randomized controlled trials that describe the use of ES in patients with peripheral nerve injury. We will compare: Electrical stimulation (application of electrical fields of constant or varying frequency) versus sham in patients with peripheral nerve injury; Electrical stimulation versus standard treatment (physiotherapy) in patients with peripheral nerve injury; Electrical stimulation versus no treatment in patients with peripheral nerve injury. Considering the scenario of very numerous strategies and different techniques of ES to stimulate nerve regeneration, decisions to recommend them should consider these uncertainties and should be summarized intended its application in clinical practice. The objective of this review is to assess the influence of electrical stimulation (ES) on nerve regeneration in individuals with peripheral nerve injury.
\end{abstract}

Keywords: Peripheral Nerves; Nerve Regeneration; Electric Stimulation Therapy; Peripheral Nerve Injury.

\section{Resumo}

Trata-se de um protocolo para uma revisão sistemática (intervenção). A estimulação elétrica (EE) é uma estratégia terapêutica utilizada para melhorar a regeneração nervosa periférica que envolve a aplicação de campos elétricos de frequência constante ou variada. Vamos conduzir uma pesquisa da literatura disponível para identificar todos os ensaios controlados randomizados publicados e não publicados que descrevem o uso de ES em pacientes com lesão nervosa periférica. Vamos comparar: Estimulação elétrica (aplicação de campos elétricos de frequência constante ou variada) versus simulação em pacientes com lesão nervosa periférica; Estimulação elétrica versus tratamento padrão (fisioterapia) em pacientes com lesão nervosa periférica; Estimulação elétrica versus nenhum tratamento em pacientes com lesão nervosa periférica. Considerando o cenário de numerosas e diferentes estratégias de EE para promover a regeneração nervosa, as decisões para recomendá-las devem considerar essas incertezas e devem ser sumarizadas visando sua aplicação na prática clínica. O objetivo desta revisão é avaliar a influência da estimulação elétrica na regeneração nervosa em indivíduos com lesão nervosa periférica.

Palavras-chave: Nervos Periféricos; Regeneração Nervosa; Terapia por Estimulação Elétrica; Traumatismos dos Nervos Periféricos. 


\section{Resumen}

Es un protocolo para una revisión sistemática (intervención). La estimulación eléctrica (EE) es una estrategia terapéutica utilizada para mejorar la regeneración nerviosa periférica que implica la aplicación de campos eléctricos de frecuencia constante o variada. Realizaremos una investigación de la literatura disponible para identificar todos los ensayos controlados aleatorios publicados y no publicados que describan el uso de EE en pacientes con daño a los nervios periféricos. Comparemos: Estimulación eléctrica (aplicación de campos eléctricos de frecuencia constante o variada) versus simulación en pacientes con lesión nerviosa periférica; Estimulación eléctrica versus tratamiento estándar (fisioterapia) en pacientes con daño a los nervios periféricos; Estimulación eléctrica versus ningún tratamiento en pacientes con daño a los nervios periféricos. Teniendo en cuenta el escenario de numerosas y diferentes estrategias de EE para promover la regeneración nerviosa, las decisiones para recomendarlas deben considerar estas incertidumbres y deben resumirse para aplicarlas en la práctica clínica. El objetivo de esta revisión es evaluar la influencia de la estimulación eléctrica en la regeneración nerviosa en individuos con daño a los nervios periféricos.

Palabras clave: Nervios Periféricos; Regeneración Nerviosa; Terapia por Estimulación Eléctrica; Traumatismos de los Nervios Periféricos.

\section{Introduction}

\subsection{Description of the Condition}

Harm to the peripheral nerves can occur due to a variety of reasons, including trauma, metabolic insults and inflammation (Stoll \& Müller, 1999). Morphological functional changes can occur in response to peripheral nerve injury, such as motor and/or sensory function impairment, hyperesthesia, and low-temperature intolerance (Stoll \& Müller, 1999; Mattos et al., 2021). Peripheral nerve regeneration occurs, but sometimes it is hampered by the type of the lesion, the presence of comorbidities such as diabetes, lesions of the musculoskeletal system and the distance from the lesion to the target organs (Dunlop et al., 2019). In the presence of these obstacles, nerve regeneration may be improved by a series of pharmacological and non-pharmacological strategies, including the use of external electric fields (Baptista et al., 2008).

\subsection{Description of the Intervention}

Electrical stimulation to improve the rate and speed of peripheral nerve regeneration involves the application of electrical fields of constant or varying frequency, as demonstrated in animal studies (Stoll \& Müller, 1999; Mattos et al., 2021; Baptista et al., 2008). Electrical currents are usually used, either flowing unidirectional (monophasic, constant, or pulsed electrical currents) or bidirectional (alternate or biphasic electrical currents) (Baptista et al., 2008). The use of bidirectional electrical currents is preferable, as it does not provoke electrophoretic phenomena and consequent skin lesion (Low \& Reed, 2001). However, this approach needs to be further investigated in human beings in clinical settings.

\subsection{How the Intervention Might Work}

The electrical currents may be administered through electrodes implanted in the nerve itself, intraoperatively, and using percutaneous or transcutaneous stimulation. The electric field improves the expression of neurotransmitters, growth factors and adhesion molecules, that may increase and guide regeneration (McCaig et al., 2005) Furthermore, it may guide endogenous stem-cells to the lesion site.

\subsection{Objective}

To assess the influence of electrical stimulation (ES) on nerve regeneration in individuals with peripheral nerve injury.

\section{Methodology}

This systematic review will be conducted in accordance with the recommendations of Cochrane Handbook for Systematic Reviews of Intervention (Cumpston et al., 2019) The protocol was prospectively registered at the PROSPERO 
database (registration number CRD42021256292) and the reporting will be prepared following the PRISMA statement (Moher et al., 2010).

\subsection{Criteria for Considering Studies for this Review}

Types of Studies

We will include randomized controlled trials (RCT).

\section{Types of Participants}

Adult patients (over 18 years old of both sexes) with peripheral nerve injury submitted to ES.

Stimulation for internal organs such as bladder, esophagus (dysphagia) or vesicle and stimulation for central neurological conditions such as stroke and spine or root or spinal cord injuries will not be included.

\section{Types of Interventions}

\section{Experimental Intervention}

We will analyze the following comparisons:

1. Electrical stimulation (application of electrical fields of constant or varying frequency) versus sham in patients with peripheral nerve injury.

2. Electrical stimulation (application of electrical fields of constant or varying frequency) versus standard treatment (physiotherapy) in patients with peripheral nerve injury.

3. Electrical stimulation (application of electrical fields of constant or varying frequency) versus no treatment in patients with peripheral nerve injury.

\section{Comparator Intervention}

We will include the following comparators:

1. Sham (i.e., a procedure that simulate ES).

2. Non-pharmacological standard treatment, including physiotherapy.

3. No intervention.

\section{Types of Outcome Measures}

\section{Primary Outcomes}

Patients will be evaluated according to:

1. Quantitative sensory tests including mechanical detection thresholds through Semmes-Weinstein monofilament, two-point discrimination, vibratory testing; and thermal detection (cold and warm) thresholds.

2. Functional status assessed through scales and/or questionnaires and functional testing.

3. Aspects related to pain, and quality of life.

\section{Secondary Outcomes}

Improvement in nerve conduction studies.

\section{Timing of Outcome Assessment}

We will extract outcomes post-intervention (i.e., at the end of the treatment) at the time points reported in the studies and group. 


\section{Hierarchy of Outcome Measures}

If studies report multiple measures of an eligible outcome, we will include the data based on several considerations. If several measures of an outcome are available on the same hierarchy level used in a study, we will prioritize the outcome measures according to the order specified for each of the outcomes. If several outcome measures on the same scale are available, we will give priority to the outcome measure that is most frequently used across all the included studies.

\subsection{Search Methods for Identification of Studies}

See also the search strategy extended data in Figshare (de Santana Ribeiro de Mattos et al., 2021).

\section{Electronic Searches}

We will conduct a literature search to identify all published and unpublished randomized controlled trials. The literature search will identify potential studies in all languages. We will translate the non-English language papers and fully assess them for potential inclusion in the review as necessary. We will place no restrictions on publication date.

We will use the following electronic search databases for identifying potential studies:

- The Cochrane Central Register of Controlled Trials (CENTRAL).

- PubMed/MEDLINE.

- EMBASE.

- PEDro.

- BVS (LILACS).

\subsection{Data Collection and Analysis}

\section{Selection of Studies}

Two reviewers authors (EM and MSV) will independently screen titles and trial abstracts that have been identified by the search strategy for potential inclusion in the review using predefined inclusion and exclusion criteria. They will assess each trial for potential duplicate publication. Differences will be resolved by discussion and consensus with a third review author (AFB or AG). The same reviewer authors will retrieve and review the complete report of all selected articles.

\subsection{Data Extraction and Management}

Two independent reviewer authors will record the following study and patient characteristics:

- Setting (single or multi-center).

- Country of origin.

- Enrolment period.

- Year of publication, format (abstract or journal article).

- Study design.

- Inclusion and exclusion criteria.

- Indications for ES.

- Types of performed ES.

- Duration and number of ES application.

- Patient demographics and characteristics including gender, mean age and co-morbidities

- Outcomes.

- Dropouts or loss to follow-up. 
- Study quality (generation of allocation sequence, allocation concealment, blinding, incomplete outcome data, selective reporting, and other bias).

\subsection{Assessment of Risk of Bias in Included Studies}

Two reviewer authors (EM e MSV) will independently assess the risk of bias for each study using version 2 of the Cochrane 'Risk of Bias' tool (RoB 2) (Sterne et al., 2019) outlined in the Cochrane Handbook for Systematic Reviews of Interventions (Cumpston et al., 2019) Any disagreements will be resolved by discussion or by involving the third review author (AFB or AG). We will assess the risk of bias of a specific result of randomized trials according to the following domains:

- Bias arising from the randomization process.

- Bias due to deviations from intended interventions.

- Bias due to missing outcome data.

- Bias in measurement of the outcome.

- Bias in selection of the reported result.

We will assess the risk of bias for the outcomes of the included trials presented in the 'Summary' table. For the purposes of this review, we are interested in quantifying the effect of ES at baseline, regardless of whether the interventions are received as intended (the intention-to-treat effect).

We will use the signaling questions in the RoB 2 tools and rate each domain as 'low risk of bias', 'some concerns', or 'high risk of bias'.

We will summarize the 'risk of bias' judgements across different studies for each of the domains listed for each outcome. The overall risk of bias within the trial for the result is the least favorable assessment across the domains; however, where a trial is judged to have some concerns for multiple domains, we will judge the overall risk of bias as high, based on the approach outlined in Table 8.2.b of the Cochrane Handbook for Systematic Reviews of Interventions (Higgins et al., 2011).

\subsection{Measures of Treatment Effect}

We will express dichotomous outcomes as risk ratios (RR) of nerve regeneration with a 95\% confidence interval (CI) and express continuous outcomes as mean differences (MD) with 95\% CIs. We will not exclude trials with zero events in both arms from meta-analysis (Friedrich et al., 2007) We will calculate the numbers of patients needed to treat (or harm) by $1 /$ (risk difference), expressed with $95 \%$ CIs. For outcomes for which data are not reported or are reported in a different format, we will contact authors for clarification. We will use the intention-to-treat (ITT) sample (all randomized patients) in the analysis.

\subsection{Unit of Analysis Issues}

We will use the patient as the unit of analysis.

\subsection{Dealing with Missing Data}

We will contact authors for any missing data from included studies.

\subsection{Assessment of Heterogeneity}

We will assess heterogeneity with the Chi2 test $(\mathrm{P}<0.15=$ significant heterogeneity) and $\mathrm{I} 2$ statistic $(>25 \%=$ heterogeneity) using a random-effects model. 


\subsection{Assessment of Reporting Biases}

We will estimate publication bias by examining the relationship between the treatment effects and the standard error of the estimate using a funnel plot.

\subsection{Data Synthesis}

If the treatments, participants, and the underlying clinical question are similar enough for a meta-analysis to be considered meaningful, we will undertake meta-analyses. For quantitative data, where possible, odds ratio (for categorical outcome data) or standardized mean differences (for continuous data) and their $95 \%$ confidence intervals will be calculated from the data generated by each included randomized controlled trial. If appropriate with available data, results from comparable groups of studies will be pooled into statistical meta-analysis using. We will use the Cochrane Review Manager 5 Software (The Nordic Cochrane Centre, 2011). Heterogeneity between combined studies will be tested using standard chisquare test. Where statistical pooling is not possible the findings will be presented in narrative form.

\subsection{Subgroup Analysis and Investigation of Heterogeneity}

We are planning to perform the following subgroup analyses a priori:

1. Risk of bias (high versus low versus unclear).

2. Publication type (abstracts versus full text).

3. Method of ES delivery.

4. Electrode placement and pulse width.

5. Age of participants.

6. Type of the lesion.

Any additional analysis will be reported as post hoc. We will compare subgroups using a formal statistical test for subgroup differences.

\subsection{Sensitivity Analysis}

We will perform a priori sensitivity analysis to assess the robustness of our conclusions. This will involve:

1. ITT versus per-protocol (PP) analysis.

2. Meta-analysis modeling (fixed versus random effects).

\section{Results and Discussion}

Numerous strategies (including different techniques of ES) have been studied over the past decades to stimulate nerve regeneration (Al-Majed et al., 2000; Al-Majed et al., 2000; Elzinga et al., 2015). Although most studies in the field were done in laboratory animals (Gordon \& Borschel, 2017), the use of electrical fields to improve peripheral nerve regeneration has been translated to the clinical practice, and some results are now found in the peer review literature, such as case studies, and randomized controlled trials (Gordon et al., 2008). However, these results have not been summarized as a metanalysis. The use of electric currents to promote peripheral nerve regeneration has been studied in experimental animal models, and, essentially, through invasive techniques. Electrical stimulation is cheaper and offer minimal potential risk for the patient (Gordon, 2016).

This review could provide useful, and practical strategies to treat patients with peripheral nerve damage.

Peripheral nerve injuries are usually underdiagnosed and undertreated. This has consequences, such as worker incapacity, with repercussions on their families and time away from work. Transection nerve injury treatments are usually 
surgical. However, strategies to speed recovery and return to function are extremely important both for the patients to have a greater chance of returning to work and to minimize costs related to associated complications.

It is fundamental for the advancement of science, and improvement of society that publications respect scientific integrity (Mesquita, 2017). Another contribution of this paper is to make clear the information on the conduct of this systematic review ensuring integrity, avoiding scientific fraud and discuss for the promotion of good practices in research.

We plan to present the results further in a final systematic review as described above in the Methodology section.

\section{Final Considerations}

This review aims to study if electrical stimulation has any influence on nerve regeneration in humans with damage on peripheral nerves, based on the RCT available in the literature. We plan to identify, critically appraise, summarize and provide the certainty about the best, currently available evidence on the effects (benefits and harms) of ES in humans.

The study findings will be published in a thesis and systematic review. This work is linked to the master's degree of Enilton de Santana Ribeiro de Mattos (Graduate Program of the Bahiana School of Medicine and Public Health, under the guidance of Prof. Abrahão Fontes Baptista and co-supervision of Prof. Alex Guedes) with a scientific, economic, and social impact.

\section{References}

Al-Majed, A. A., Brushart, T. M., \& Gordon, T. (2000). Electrical stimulation accelerates and increases expression of BDNF and trkB mRNA in regenerating rat femoral motoneurons. The European journal of neuroscience, 12(12), 4381-4390.

Al-Majed, A. A., Neumann, C. M., Brushart, T. M., \& Gordon, T. (2000). Brief electrical stimulation promotes the speed and accuracy of motor axonal regeneration. The Journal of neuroscience: the official journal of the Society for Neuroscience, 20(7), 2602-2608. https://doi.org/10.1523/JNEUROSCI.20-0702602.2000

Baptista, A. F., Gomes, J. R., Oliveira, J. T., Santos, S. M., Vannier-Santos, M. A., \& Martinez, A. M. (2008). High- and low-frequency transcutaneous electrical nerve stimulation delay sciatic nerve regeneration after crush lesion in the mouse. Journal of the peripheral nervous system: JPNS, 13(1), 71-80. https://doi.org/10.1111/j.1529-8027.2008.00160.x

Cumpston, M., Li, T., Page, M. J., Chandler, J., Welch, V. A., Higgins, J. P., \& Thomas, J. (2019). Updated guidance for trusted systematic reviews: a new edition of the Cochrane Handbook for Systematic Reviews of Interventions. The Cochrane database of systematic reviews, 10 , ED000142. https://doi.org/10.1002/14651858.ED000142

de Santana Ribeiro de Mattos, E., Guedes, A., Baptista, A. F., \& Viana, M. dos S. (2021). Search Strategy Extended Data [Data set]. figshare. https://doi.org/10.6084/M9.FIGSHARE.15134877.V1

Dunlop, R., Wormald, J., \& Jain, A. (2019). Outcome of surgical repair of adult digital nerve injury: a systematic review. BMJ open, 9(3), e025443. https://doi.org/10.1136/bmjopen-2018-025443

Elzinga, K., Tyreman, N., Ladak, A., Savaryn, B., Olson, J., \& Gordon, T. (2015). Brief electrical stimulation improves nerve regeneration after delayed repair in Sprague Dawley rats. Experimental neurology, 269, 142-153. https://doi.org/10.1016/j.expneurol.2015.03.022

Friedrich, J. O., Adhikari, N. K., \& Beyene, J. (2007). Inclusion of zero total event trials in meta-analyses maintains analytic consistency and incorporates all available data. BMC medical research methodology, 7, 5. https://doi.org/10.1186/1471-2288-7-5

Gordon, T., \& Borschel, G. H. (2017). The use of the rat as a model for studying peripheral nerve regeneration and sprouting after complete and partial nerve injuries. Experimental neurology, 287(Pt 3), 331-347. https://doi.org/10.1016/j.expneurol.2016.01.014

Gordon, T., Brushart, T. M., \& Chan, K. M. (2008). Augmenting nerve regeneration with electrical stimulation. Neurological research, 30(10), 1012-1022. https://doi.org/10.1179/174313208X362488

Gordon T. (2016). Electrical Stimulation to Enhance Axon Regeneration After Peripheral Nerve Injuries in Animal Models and Humans. Neurotherapeutics: the journal of the American Society for Experimental NeuroTherapeutics, 13(2), 295-310. https://doi.org/10.1007/s13311-015-0415-1

Higgins, J. P., Altman, D. G., Gøtzsche, P. C., Jüni, P., Moher, D., Oxman, A. D., Savovic, J., Schulz, K. F., Weeks, L., Sterne, J. A., Cochrane Bias Methods Group, \& Cochrane Statistical Methods Group (2011). The Cochrane Collaboration's tool for assessing risk of bias in randomised trials. BMJ (Clinical research ed.), 343, d5928. https://doi.org/10.1136/bmj.d5928

Low, J., \& Reed, A. (2001). Electrotherapy explained: principles and practice. Butterworth-Heinemann. 
Research, Society and Development, v. 10, n. 17, e230101724942, 2021

(CC BY 4.0) | ISSN 2525-3409 | DOI: http://dx.doi.org/10.33448/rsd-v10i17.24942

Mattos, E., Guedes, A., Lessa, P., \& Baptista, A. F. (2021). Influence of surface peripheral electrical stimulation on nerve regeneration after digital nerve neurorrhaphy: study protocol for a randomized clinical trial. F1000Research, 10, 219. https://doi.org/10.12688/f1000research.42120.2

McCaig, C. D., Rajnicek, A. M., Song, B., \& Zhao, M. (2005). Controlling cell behavior electrically: current views and future potential. Physiological reviews, 85(3), 943-978. https://doi.org/10.1152/physrev.00020.2004

Mesquita, C.T. (2017). Integrity in scientific research. International Journal of Cardiovascular Sciences. 30(1),1-3. https://www.scielo.br/j/ijcs/a/TJWJ4SNLVK7g6ydkYBzS3Ln/?format=pdf\&lang=en

Moher, D., Liberati, A., Tetzlaff, J., Altman, D. G., \& PRISMA Group (2010). Preferred reporting items for systematic reviews and meta-analyses: the PRISMA statement. International journal of surgery (London, England), 8(5), 336-341. https://doi.org/10.1016/j.ijsu.2010.02.007

Sterne, J., Savović, J., Page, M. J., Elbers, R. G., Blencowe, N. S., Boutron, I., Cates, C. J., Cheng, H. Y., Corbett, M. S., Eldridge, S. M., Emberson, J. R., Hernán, M. A., Hopewell, S., Hróbjartsson, A., Junqueira, D. R., Jüni, P., Kirkham, J. J., Lasserson, T., Li, T., McAleenan, A., \& Higgins, J. (2019). RoB 2: a revised tool for assessing risk of bias in randomised trials. BMJ (Clinical research ed.), 366, 14898. https://doi.org/10.1136/bmj.14898

Stoll, G., \& Müller, H. W. (1999). Nerve injury, axonal degeneration and neural regeneration: basic insights. Brain pathology (Zurich, Switzerland), 9(2), 313325. https://doi.org/10.1111/j.1750-3639.1999.tb00229.x

The Nordic Cochrane Centre, The Cochrane Collaboration. Review Manager (RevMan) Version 5.1.1 (2011). Copenhagen: The Nordic Cochrane Centre. https://revman.cochrane.org/\#/myReviews 